\title{
A nanocrystalline zirconium carbide coating as a functional corrosion-resistant barrier for polymer electrolyte membrane fuel cell application
}

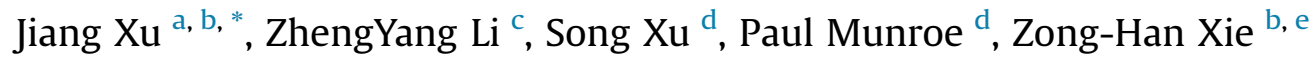 \\ a Department of Material Science and Engineering, Nanjing University of Aeronautics and Astronautics, 29 Yudao Street, Nanjing 210016, PR China \\ b School of Mechanical \& Electrical Engineering, Wuhan Institute of Technology, 693 Xiongchu Avenue, Wuhan 430073, PR China \\ ${ }^{c}$ Institute of Mechanics, Chinese Academy of Sciences, Beijing 100190, PR China \\ ${ }^{\mathrm{d}}$ School of Materials Science and Engineering, University of New South Wales, NSW 2052, Australia \\ e School of Mechanical Engineering, University of Adelaide, SA 5005, Australia
}

\section{H I G H L I G H T S}

- A ZrC coating exhibits a dense, homogeneous microstructure.

- The corrosion resistance of the coating is higher than that of Ti6Al4V substrate.

- The ZrC coating exhibits good hydrophobic and low interfacial contact resistance.

\section{A R T I C L E I N F O}

\section{Article history:}

Received 25 May 2015

Received in revised form

6 August 2015

Accepted 7 August 2015

Available online 25 August 2015

\section{Keywords:}

Polymer electrolyte membrane fuel cell

(PEMFC)

Bipolar plate

Titanium alloy

ZrC coating

Corrosion resistance

\begin{abstract}
A B S T R A C T
A $\mathrm{ZrC}$ nanocrystalline coating is engineered onto a Ti-6Al-4V substrate using a double cathode glow discharge technique in order to improve the corrosion resistance and long-term stability of this alloy. The new coating exhibits an extremely dense, homogeneous microstructure composed of equiaxed grains with an average grain size of $\sim 12 \mathrm{~nm}$ and is well adhered on the surface of the substrate. The corrosion behaviour of the coating is systematically investigated using various electrochemical methods, including potentiodynamic, potentiostatic polarizations and electrochemical impedance spectroscopy (EIS), in a simulated polymer electrolyte membrane fuel cell (PEMFC) operating circumstances under different temperatures. The results show that with rising temperature, the corrosion potential $\left(\mathrm{E}_{\mathrm{corr}}\right)$ decreases and the corrosion current density $\left(i_{\text {corr }}\right)$ of the $\mathrm{ZrC}$ coated specimen increases, indicating that the corrosion resistance decreased with increasing temperature. However, at a given temperature, the $\mathrm{ZrC}$ coated Ti-6Al- $4 \mathrm{~V}$ alloy has a higher $\mathrm{E}_{\mathrm{corr}}$ and lower $\mathrm{i}_{\text {corr }}$ as compared to the bare substrate. The results of EIS measurements show that the values of the resistance for the $\mathrm{ZrC}$ coated $\mathrm{Ti}-6 \mathrm{Al}-4 \mathrm{~V}$ alloy are three orders of magnitude larger than those of $\mathrm{Ti}-6 \mathrm{~A} 1-4 \mathrm{~V}$ in the simulated PEMFC environment.
\end{abstract}

๑) 2015 Elsevier B.V. All rights reserved.

\section{Introduction}

As an energy-producing device, fuel cells can directly convert the chemical energy of fuel and oxidant into electrical energy via an electrochemical reaction. They are designed to operate at high efficiencies over a wide range of operating conditions with water as the only byproduct, and thus, have received extensive attention as

\footnotetext{
* Corresponding author. Department of Material Science and Engineering Nanjing University of Aeronautics and Astronautics, 29 Yudao Street, Nanjing 210016, PR China.

E-mail address: xujiang73@nuaa.edu.cn (J. Xu).
}

one of the cleanest and most sustainable solutions to meet future energy needs [1]. Among the many types of fuel cells, the polymer electrolyte membrane fuel cell (PEMFC) is one of the most promising candidates for automobile and portable power applications, due to its high efficiency of energy conversion, low temperature operation, quick start-up time and environmentally friendly, nearzero emissions [2]. Bipolar plates, as one of the major components in the PEMFC stacks, constitute approximately $80 \%$ of the total weight, $30 \%$ of the total cost and almost all of the volume in a typical fuel cell stacks [3]. Bipolar plates perform multiple functions; that is, conducting currents between cells, supporting the cell stack, managing the heat and water of the cells, and 
distributing the cathodic and anodic reactant gases uniformly. Ideally, bipolar plates should have excellent corrosion resistance in the PEMFC environment, high electrical conductivity to reduce resistive losses, suitable surface properties for water removal, low gas permeability, light weight with good mechanical strength, and low manufacturing cost etc. [4,5]. Owing to their excellent corrosion resistance and electrical conductivity, graphite and graphite composite have been widely used in the manufacture of bipolar plates [6]. Nevertheless, their commercial application is plagued by some complex problems, including poor barrier to reactant gases, insufficient mechanical strength and high manufacturing cost. In comparison, metals have a significant advantage over graphitebased materials in terms of cost, mechanical strength, ease of manufacture and specific volumetric power density. Therefore, metallic bipolar plates, particularly those fabricated from different grades of stainless steels, have received much attention, and are considered to have the greatest potential as an alternative material for the widely used non-porous graphite $[7,8]$. When applying stainless steels to bipolar plates for PEMFCs, the passive film formed on their surfaces in the highly acidic environment of the fuel cell acts, in part, as an electrical insulator and, thus, increases the contact resistance between the electrode and the bipolar plate, resulting in a decrease in cell performance [9]. In addition, due to their insufficient corrosion resistance, the release of metallic ions, e.g. Fe, $\mathrm{Cr}$ and $\mathrm{Ni}$ ions from stainless steel, leads to contamination of the polymer electrolyte and Pt catalyst [10]. As compared to stainless steel, titanium and its alloys are a better alternative for the fabrication of metallic bipolar plates for portable applications, because they can produce higher volumetric power densities when assembled into stacks [11]. Surface modification by the deposition of a protective coating is commonly used to improve and control the corrosion resistance of metals without changing the bulk properties of the metal substrate. Therefore, in recent studies, various types of thin, noble metal coatings, such as gold and platinum, have been employed to protect bipolar plates made of titanium and its alloys from the formation of oxide layers with a high resistivity in the PEMFC environment [12-15]. For example, Wang et al. [13] found that the cell performance of the gold-plated bipolar plates is close to, and often superior than, the PEM fuel cells with graphite and uncoated titanium bipolar plates. It is worth noting that in addition to good corrosion protection, low electrical contact resistance, high mechanical strength, excellent adhesion between the coating and the substrate and low fabrication cost are also key factors to the application of a protective coating on these metallic bipolar plates. However, the corrosion resistance of these noble metal coatings has not been systematically investigated. Further, the cost of these noble metals is prohibitive for commercial application in PEMFCs, even in the form of thin coatings.

As a transition metal carbide, $\mathrm{ZrC}$ exhibits both ceramic and metallic characteristics including a very high melting point $\left(>3540{ }^{\circ} \mathrm{C}\right)$, high hardness, excellent corrosion resistance and high electrical and thermal conductivities [16-18]. The unique combination of these physical and chemical properties makes it a potential coating material for the PEMFC application. To date, however, transition metal nitride or carbide coatings fabricated by various deposition techniques (such as e-beam evaporation and sputtering) have been of poor quality due to the presence of defects, such as pinholes, pores and macro-droplets, which severely reduce their corrosion resistance $[19,20]$. To address this issue, a double glow discharge plasma technique has been utilized for hard coating synthesis in our recent work, which yielded thick, dense coatings on titanium alloy substrates, which are strong and effective in combating corrosion attack [21].

In this study, the application of $\mathrm{ZrC}$ as a functional protective coating for PEMFC bipolar plates is explored. To so do, a $\mathrm{ZrC}$ nanocrystalline coating was deposited onto a Ti-6A $1-4 \mathrm{~V}$ substrate using a double glow discharge plasma technique. The microstructure of the as-deposited coating was characterized by X-ray diffraction (XRD), scanning electron microscopy (SEM), energy-dispersive X-ray spectroscopy (EDS) and transmission electron microscopy (TEM). The mechanical properties and adhesion strength of the as-deposited coating were measured using nanoindentation and scratch testing. Considering that the bipolar plates operate in a wide range of temperatures in PEMFC, the corrosion behaviour of the $\mathrm{ZrC}$ coating in simulated PEMFC environments was investigated using electrochemical techniques at three solution temperatures of 25,55 and $70{ }^{\circ} \mathrm{C}$. Furthermore, the interfacial contact resistance and surface wettability of the $\mathrm{ZrC}$ coated specimen were measured and compared with the uncoated $\mathrm{Ti}-6 \mathrm{~A} 1-4 \mathrm{~V}$ alloy.

\section{Experimental details}

\subsection{Preparation of ZrC nanocrystalline coating}

The $\mathrm{ZrC}$ nanocrystalline coating were deposited onto a Ti-6A1-4V substrate using a double cathode glow discharge apparatus. In the process of double cathode glow discharge, one cathode serves as the target fabricated from the desired sputtering materials, and the other cathode as the substrate material, as described elsewhere [21]. When two different voltages are applied to the two cathodes, glow discharge occurs. In this work, a ZrC disk with dimensions $\Phi 80 \times 4 \mathrm{~mm}$ was used as the sputtering target. It was fabricated from ball-milled $\operatorname{Zr}$ (300 mesh, >99.9\% purity) and C powders (graphite, 500 mesh, $>99.9 \%$ purity) by employing cold compaction under a pressure of $600 \mathrm{MPa}$. Disk-shaped substrates, $40 \mathrm{~mm}$ in diameter and $3 \mathrm{~mm}$ thick, were machined from a commercial Ti-6Al-4V alloy rod. The nominal composition of this alloy in weight percent is: $\mathrm{Al}, 6.04 ; \mathrm{V}, 4.03 ; \mathrm{Fe}, 0.3 ; \mathrm{O}, 0.1 ; \mathrm{C}, 0.1 ; \mathrm{N}, 0.05$; $\mathrm{H}, 0.015$ and the balance Ti. Before sputter deposition, the polished substrates were ultrasonically cleaned in acetone, alcohol, distilled water and then dried. The detailed deposition parameters can be described as follows: the base pressure, $5 \times 10^{-3} \mathrm{~Pa}$; working pressure, $35 \mathrm{~Pa}$; target electrode bias voltage with direct current, $-750 \mathrm{~V}$; substrate bias voltage with impulse current, $-350 \mathrm{~V}$; substrate temperature, $650{ }^{\circ} \mathrm{C}$; target/substrate distance, $10 \mathrm{~mm}$ and treatment time, $2 \mathrm{~h}$.

\subsection{Phase and microstructure characterization}

The phase composition of the as-deposited coating was characterized using X-ray diffraction (XRD) (D8ADVANCE using $\mathrm{Cu} \mathrm{K \alpha}$ radiation), with the instrument operating at $35 \mathrm{kV}$ and $40 \mathrm{~mA}$. Xray data were collected using a $0.1^{\circ}$ step scan with a count time of $1 \mathrm{~s}$. Atomic force microscopy (AFM; Veeco Nanoscope V) was used to characterize the surface features and to determine roughness values of the as-deposited coating. Both the cross-sectional and corroded surface morphology of the as-deposited coatings were studied by scanning electron microscopy (SEM, Quanta200, FEI Company). Transmission electron microscopy (TEM) and highresolution TEM (HRTEM) images were performed using a JEOL JEM-2010 operating at an accelerating voltage of $200 \mathrm{kV}$. Thin-foil specimens for TEM observation were prepared by single-jet electropolishing from the untreated side of the substrate. X-ray photoelectron spectroscopy (XPS) measurements were performed with a Kratos AXIS Ultra ESCA System using an Al Ka X-ray source with energy of $1486.71 \mathrm{eV}$. The accelerating voltage and emission current of the X-ray source were kept at $12 \mathrm{kV}$ and $12 \mathrm{~mA}$, respectively. The base pressure of the sample analysis chamber was maintained at $\sim 10^{-10}$ Torr. The pass energy was selected to be $80 \mathrm{eV}$ 
for survey scans and $10 \mathrm{eV}$ for feature scans to ensure both high resolution and good sensitivity. After subtracting the background signal, the spectra were fitted by both Gaussian and mixed Gaussian/Lorentzian functions. Peak positions were then calibrated with respect to the $\mathrm{C} 1 \mathrm{~s}$ peak at $284.8 \mathrm{eV}$ originating from hydrocarbon contamination. Peak identification was performed with reference to the NIST XPS database (V4.0).

\subsection{Electrochemical measurements}

Electrochemical measurements were carried out in a $0.5 \mathrm{M}$ $\mathrm{H}_{2} \mathrm{SO}_{4}+2 \mathrm{ppm}$ HF solution to simulate the aggressive PEMFCs environment using a $\mathrm{CHI} 660 \mathrm{C}$ electrochemical workstation. The temperatures of solution were controlled to be $25{ }^{\circ} \mathrm{C}, 55^{\circ} \mathrm{C}$ and $70{ }^{\circ} \mathrm{C}$, respectively. A standard three-compartment cell was used with a working electrode, a platinum sheet as the counter electrode and a saturated calomel electrode (SCE) insulated with a Luggins capillary to avoid chloride contamination as a reference electrode. Each specimen was used as a working electrode and was connected to a conducting wire and then embedded with non-conducting epoxy resin leaving a square surface of approximately $1 \mathrm{~cm}^{2}$ exposed to the solution. Throughout this study, all electrode potentials were referred to the SCE. The potentiodynamic current-potential curves were recorded at a sweep rate of $20 \mathrm{mV} \mathrm{min}^{-1}$. Prior to the potentiodynamic sweep, the specimens were polarized cathodically for $10 \mathrm{~min}$ at $-1.0 \mathrm{~V}_{\mathrm{SCE}}$ to remove any remnant oxide from the specimens. EIS measurement started after stabilization for about $1 \mathrm{~h}$ at open-circuit potential (OCP). The frequency was swept from $100 \mathrm{kHz}$ down to $10 \mathrm{mHz}$, with an acquisition of 12 points per decade of frequency and an amplitude of the AC signal of $10 \mathrm{mV}$.

\subsection{Interfacial contact resistance (ICR) and contact angle measurements}

Interfacial contact resistance (ICR) values of the uncoated and $\mathrm{ZrC}$ coated $\mathrm{Ti}-6 \mathrm{Al}-4 \mathrm{~V}$ were determined using methods described in detail elsewhere [22]. In this experimental setup, two pieces of conductive carbon paper (Toray TGP-H-090) were sandwiched between the sample and two copper plates that were plated with gold on both sides to increase electrical conductivity. A constant electrical current of $0.5 \mathrm{~A}$ was applied via the two copper plates and the variation in the total voltage was recorded as a function of a steadily increasing compaction force up to $260 \mathrm{~N} \mathrm{~cm}^{-2}$. The resistance of the carbon paper/copper plate interfaces was also measured to calibrate the ICR between the sample and carbon paper. The $\mathrm{ZrC}$ coated and bare $\mathrm{Ti}-6 \mathrm{Al}-4 \mathrm{~V}$ before and after potentiostatic polarization at a cathode potential of $+0.6 \mathrm{~V}_{\mathrm{SCE}}$ for 120 min in $0.5 \mathrm{M} \mathrm{H}_{2} \mathrm{SO}_{4}+2 \mathrm{ppm} \mathrm{HF}$ solution at $70{ }^{\circ} \mathrm{C}$, were also investigated to understand the influence of any corrosion on ICR. The procedure used for calculating the ICR values of $\mathrm{ZrC}$ coated Ti-6Al-4V is based upon a method described by Fukutsuka et al. [23]. The hydrophobicity of the sample surfaces was evaluated by contact angle analysis using the sessile drop method. An equal volume of distilled water was dropped carefully onto each sample by means of a micropipette. All measurements were made using a contact-angle meter (JC2000C, POWEREACH). Each measurement was repeated three times for average value.

\section{Results and discussion}

\subsection{Phase identification and microstructural characterization}

Fig. 1 shows the typical XRD pattern recorded from the asdeposited $\mathrm{ZrC}$ coating. All the diffraction peaks acquired from the as-deposited coating can be indexed as face centered cubic (fcc) B1$\mathrm{NaCl}-$ structured ZrC (JCPDS No. 35-0784). The diffraction peak intensity of the (111) reflection of $\mathrm{ZrC}$ phase recorded from the coating is significantly higher than that of the corresponding standard powder diffraction pattern, suggesting that this coating has a strong preferred (111) crystallographic texture. According to the intensity data, the texture coefficient $\left(T C_{h k l}\right)$ was calculated through the following equation [24]:

$T C_{h k l}=\frac{I_{m}(h k l) / I_{0}(h k l)}{\frac{1}{n} \sum_{1}^{n} I_{m}(h k l) / I_{0}(h k l)}$

where $I_{m}(h k l)$ is the measured X-ray relative intensity of the (hkl) plane, $I_{0}(h k l)$ is the relative intensity in the powder pattern, $(h k l)$ represents the indices of the reflection plane and $\mathrm{n}$ is the number of reflection planes. For a $T C_{h k l}$ value greater than 1, a preferred orientation is developed towards a specific crystalline plane; while a $T C_{h k l}$ value close to 1 signifies a more random orientation and a $T C_{h k l}$ value in the range from 0 to 1 denotes a lack of grain orientation for the specific plane under consideration [25]. The calculated texture coefficients for different planes for the as-deposited $\mathrm{ZrC}$ coating are listed in Table 1 . A strong (111) texture for the $\mathrm{ZrC}$ coating is further confirmed by the calculated results shown in Table 1. During coating growth, the development of crystallographic texture in the $\mathrm{ZrC}$ coating is understood to have occurred to minimize the total energy of the system, which is regulated by the competition between the strain and the surface energies [26]. For $\mathrm{B} 1-\mathrm{NaCl}-$ structured $\mathrm{ZrC}$, the (111) plane has the lowest strain energy, due to anisotropy of Young's modulus, and the preferred (111) orientation is expected to develop under strain energy dominated growth. On the other hand, the (200) plane in the ZrC crystal represents the plane of lowest surface energy and is expected to develop when surface energy is the dominant contributor to the total energy. The observed change of the preferred orientation from (200) to (111) may be related to the increase of the energy of bombarding particles, deposition temperature and coating thickness [27]. For example, Ding et al. [28] found that under high deposition temperatures, the atomic mobility and surface diffusion increased, which was favourable for the development of the (111) texture rather than the (200) texture. This observation is thus consistent with the relatively high deposition temperature used in this work. Moreover, it is evident that the XRD pattern of the coating displays wide peaks with relatively low intensity, which is

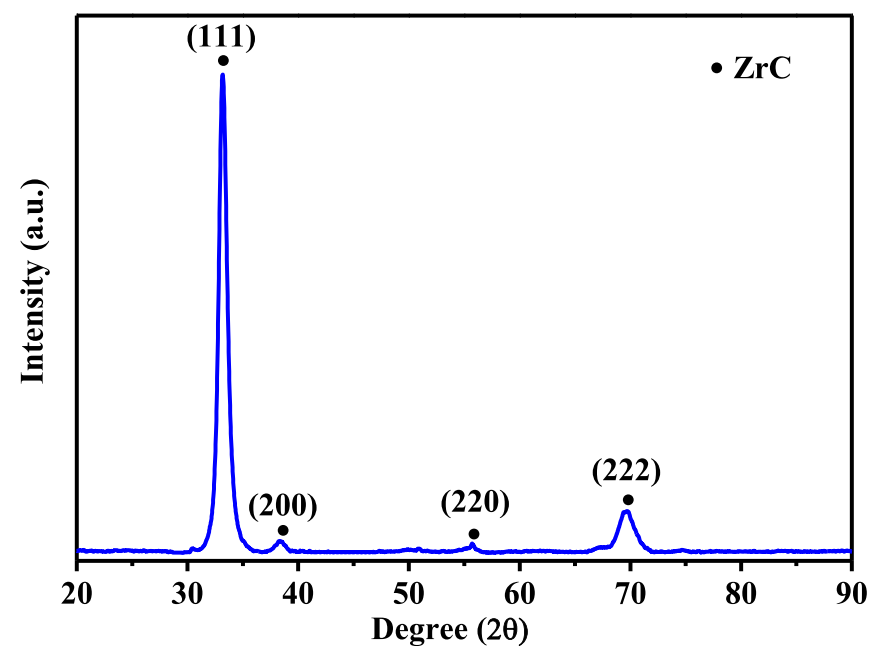

Fig. 1. Typical X-ray diffraction pattern taken from the as-deposited $\mathrm{ZrC}$ coating. 
Table 1

The calculated texture coefficients of different planes for the $\mathrm{ZrC}$ coating.

\begin{tabular}{lllll}
\hline Crystal plane & $(111)$ & $(200)$ & $(220)$ & $(222)$ \\
$\mathrm{T}(\mathrm{hkl})$ & 2.62 & 0.08 & 0.09 & 0.98 \\
\hline
\end{tabular}

characteristic of nanocrystalline materials. The average grain sizes of the coating was estimated to be $\sim 10 \mathrm{~nm}$ by applying the Scherrer formula for peak broadening of the low angle (002) reflection, after the correction of instrumental line broadening [29].

Fig. 2(a) shows representative three-dimensional AFM images of the surface morphologies of the polished $\mathrm{Ti}-6 \mathrm{Al}-4 \mathrm{~V}$ substrate before and after sputter deposition. There are some parallel grooves evident induced from mechanical polishing on the surface of the bare substrate with an average root-mean-square roughness ( $\mathrm{Rq}$ ) of $3.2 \mathrm{~nm}$, as shown in Fig. 2a. The surface of the $\mathrm{ZrC}$ coating exhibits a forest-like morphology and the value of $\mathrm{R}_{\mathrm{q}}$ increases to about $5.3 \mathrm{~nm}$ after deposition (Fig. 2b). Thus, this coating is smoother than those commonly obtained by other authors using other deposition methods $[30,31]$. The smooth surface of the $\mathrm{ZrC}$ coating may also be related to high deposition temperature employed, which promotes the diffusion of atoms and thus reduces the roughness of coating [32]. It is known that a lower surface roughness implies a lower surface defect density and endows the coatings with a higher corrosion protection to the underlying substrate [33]. Fig. 2(c)-(e) displays the scanning electron microscopy crosssectional image and the corresponding EDS elemental maps for Ti and $\mathrm{Zr}$ of the $\mathrm{ZrC}$ coating deposited on a $\mathrm{Ti}-6 \mathrm{~A} 1-4 \mathrm{~V}$ substrate. It is evident that the $\mathrm{ZrC}$ coating, with a thickness of about $16 \mu \mathrm{m}$, exhibits a homogeneous and continuous microstructure with homogeneous distribution of chemical composition, and is adherent to the substrate. No defects, such as pinholes, macro-droplets or microcracks, are visible either within the coating cross-section or the coating-substrate interface. The lack of such defects will be beneficial to hinder the inward diffusion of corrosive species into the underlying substrate. Plan-view TEM bright-field/dark-field images of the ZrC coating are shown in Fig. 2(f) and (g), together with corresponding selected area electron diffraction (SAED) pattern. It is clear that the coating is composed of equiaxed grains. A statistical grain size distribution was determined by direct measurement of about 200 grains on TEM dark-field micrographs of some samples. The diameter of grain range from 8 to $15 \mathrm{~nm}$, and the average grain size was about $12 \mathrm{~nm}$. The average grain size is slightly larger than the values deduced from the Scherrer equation based on XRD data, which is attributed to the presence of structural defects (i.e. stacking faults or low-angle grain boundaries) and the disordered character of grain boundaries [34,35]. The selected area electron diffraction (SAED) pattern (inset in Fig. 2(g)) reveals the crystalline nature of the as-deposited coating and the strong diffracted intensity of the (111) ring provides further evidence of the $\mathrm{ZrC}$ coating with a (111) texture, which is in agreement with the XRD data. As expected, from a bright-field HRTEM lattice image (Fig. 2(g)), lattice fringes of $0.271 \mathrm{~nm}$ marked with dotted circles are most frequently observed. These correspond to the d-spacing value of the (111) plane of $\mathrm{B} 1-\mathrm{NaCl}-$ structured $\mathrm{ZrC}$.

\subsection{Electrochemical corrosion}

\subsubsection{Open circuit potentials}

Fig. 3 displays the curves of the open circuit potential ( $\left.E_{O C P}\right)$ of the $\mathrm{ZrC}$ coated and bare $\mathrm{Ti}-6 \mathrm{~A} 1-4 \mathrm{~V}$ as a function of immersion time when immersed in a $0.5 \mathrm{M} \mathrm{H}_{2} \mathrm{SO}_{4}+2 \mathrm{ppm}$ HF solution at temperatures of 25,55 and $70{ }^{\circ} \mathrm{C}$. The OCP-time curves reflect the electrochemical processes taking place on the samples during immersion. In general, a shift of the open circuit potential in the positive direction indicates the formation of a passive film, while a shift in the negative direction may be the consequence of local breakdown or dissolution of the film, or no film formation. As shown in Fig. 3, for both specimens, the EOCP values moves smoothly in the positive direction at the beginning of a few hundred second, followed by reaching a steady-state potential with increasing immersion time, indicating that both the $\mathrm{ZrC}$ coated and bare $\mathrm{Ti}-6 \mathrm{~A} 1-4 \mathrm{~V}$ exhibit a passive behaviour in a $0.5 \mathrm{M}$ $\mathrm{H}_{2} \mathrm{SO}_{4}+2 \mathrm{ppm}$ HF solution at the different temperatures studied. With increasing temperature, the values for steady potential decrease and the times taken to reach a steady $\mathrm{E}_{\mathrm{OCP}}$ become longer, accordingly. The displacement of the $\mathrm{E}_{\mathrm{OCP}}$ for bare $\mathrm{Ti}-6 \mathrm{~A} 1-4 \mathrm{~V}$ with increasing temperature is more significant than that for the $\mathrm{ZrC}$ coating, indicating that the $\mathrm{ZrC}$ coated specimen is electrochemically more inactive in comparison to uncoated $\mathrm{Ti}-6 \mathrm{~A} 1-4 \mathrm{~V}$. At a given temperature, the $\mathrm{ZrC}$ coating exhibits a higher steady $\mathrm{E}_{\mathrm{OCP}}$ and more rapidly attains a steady $\mathrm{E}_{\mathrm{OCP}}$, as compared to bare $\mathrm{Ti}-6 \mathrm{~A} 1-4 \mathrm{~V}$. This implies that the formation of a protective passive film with a higher stability is faster for the $\mathrm{ZrC}$ coated specimen. There are two opposite effects of solution temperature on the electrochemical processes of the tested samples. On the one hand, a high solution temperature promotes more rapid growth of passive films on the specimen surface, leading to the ennoblement of the specimen [36]. On the other hand, temperature enhances the interaction intensity between the electrolyte and the specimen surface and favours the kinetics of corrosion reactions [37].

\subsubsection{Potentiodynamic polarization studies and XPS analysis}

Potentiodynamic polarisation curves of the $\mathrm{ZrC}$ coated and bare $\mathrm{Ti}-6 \mathrm{~A} 1-4 \mathrm{~V}$ in a $0.5 \mathrm{M} \mathrm{H}_{2} \mathrm{SO}_{4}+2 \mathrm{ppm}$ HF solution were obtained at different temperatures (Fig. 4(a) and (b)) to demonstrate the influence of temperature on the corrosion behaviour of both samples. As shown in Fig. 4(a) and (b), at all temperatures, the current density of the cathodic branch rises steadily as the potential decreases, and it moves to higher values with temperature. This behaviour is because high temperatures enhance the transport of reaction agents to the specimen surface, increasing the cathodic reaction rate, which speeds up cathodic reactions, such as the reduction of hydrogen ions [38]. At the three investigated temperatures, there exists a wide potential plateau in the anodic branch where the current density is independent of potential. When temperature increases from 25 to $70{ }^{\circ} \mathrm{C}$, the anodic current densities of uncoated $\mathrm{Ti}-6 \mathrm{~A} 1-4 \mathrm{~V}$ increases notably, from the order of magnitude of $10^{-5} \mathrm{~A} \mathrm{~cm}^{-2}$ to $10^{-3} \mathrm{~A} \mathrm{~cm}^{-2}$, whereas negligible variation in the anodic current densities, being of the order of magnitude of $\sim 10^{-7} \mathrm{~A} \mathrm{~cm}^{-2}$, is observed for the $\mathrm{ZrC}$ coated specimen. It is generally believed that by increasing the temperature, the number of defects in the passive film increases, and thus the passive layer is less protective at higher temperatures $[39,40]$. The above results show that the relative increase in the number of defects in the passive film with increasing temperature for the $\mathrm{ZrC}$ coated specimen is significantly lower than that for uncoated Ti-6A1-4V. The electrochemical parameters derived from the polarization curves are summarized in Table 2. Moreover, with increasing temperature, the corrosion potentials of the tested samples are slightly displaced toward less noble values, which follows the same tendency as their ЕОСP values, meanwhile, corrosion current densities $i_{\text {corr }}$ increase, indicative of degraded corrosion resistance. The solution temperature has a more pronounced influence on the position of the corrosion potentials of uncoated $\mathrm{Ti}-6 \mathrm{~A} 1-4 \mathrm{~V}$ than that of the $\mathrm{ZrC}$ coated specimen. At the same temperature, the $\mathrm{E}_{\text {corr }}$ value of the $\mathrm{ZrC}$ coated specimen is $0.5-0.6 \mathrm{~V}_{\mathrm{SCE}}$ higher than that of uncoated $\mathrm{Ti}-6 \mathrm{~A} 1-4 \mathrm{~V}$, while the corrosion current density $\left(i_{\text {corr }}\right)$ of the $\mathrm{ZrC}$ coated specimen is more 

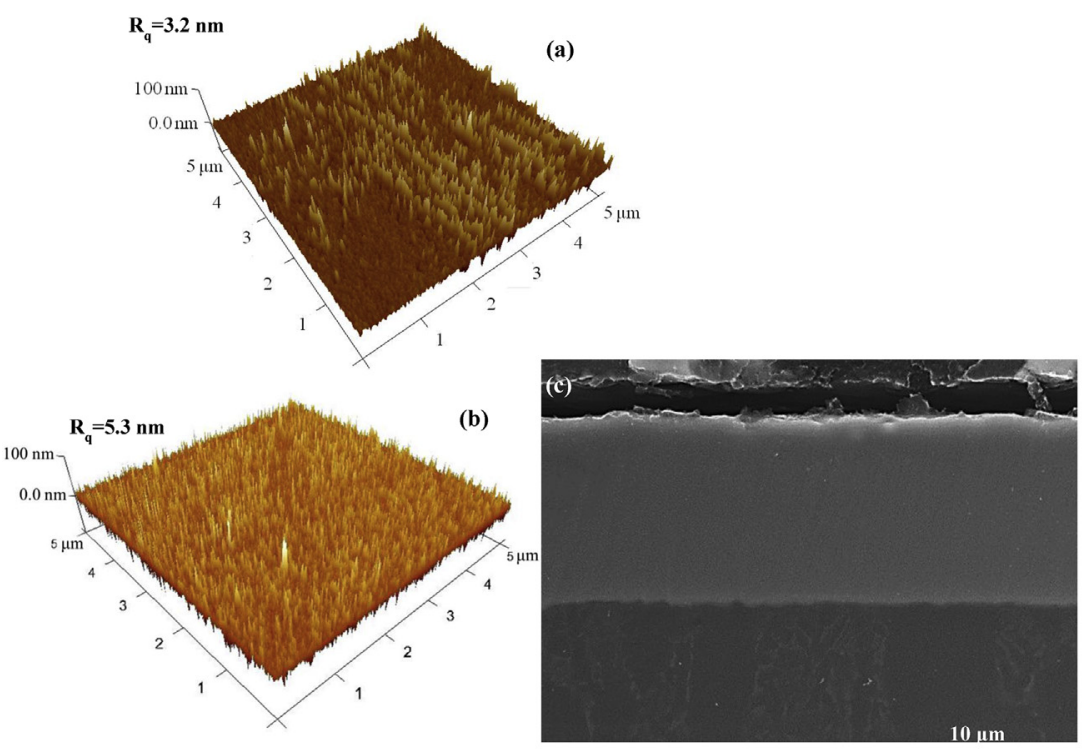
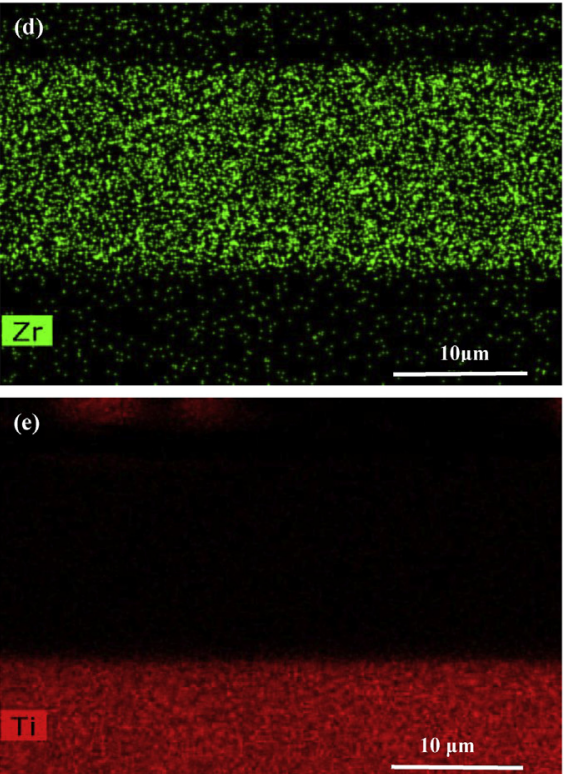
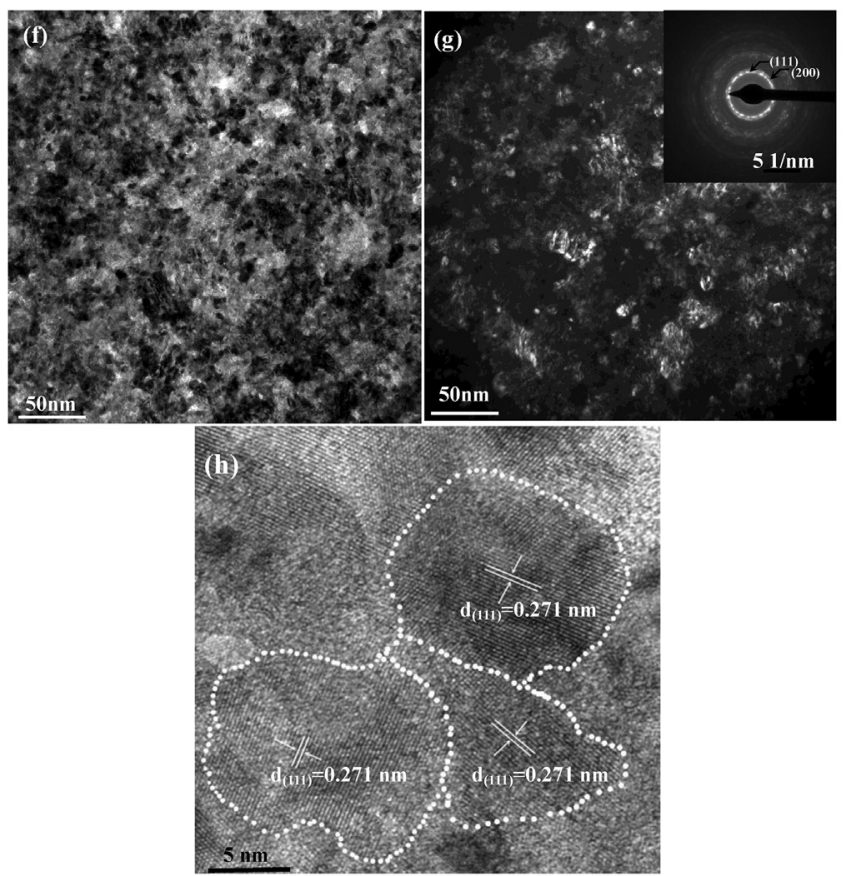

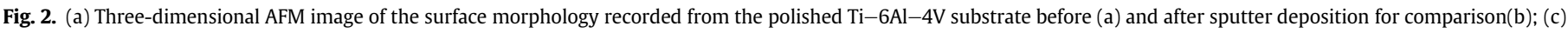

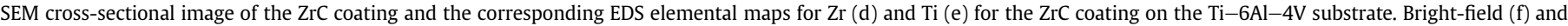

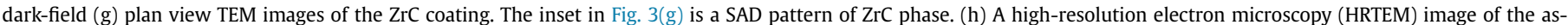
deposited $\mathrm{ZrC}$ coating.

than 3-4 orders of magnitude lower than that of uncoated $\mathrm{Ti}-6 \mathrm{~A} 1-4 \mathrm{~V}$. The lower $i_{\text {corr }}$ means that the $\mathrm{ZrC}$ coated sample would be eroded more slowly than the uncoated sample. It is worth noting that at the same temperature, the corrosion potentials obtained from the potentiodynamic curves are lower than the values of $E_{\mathrm{OCP}}$, since the two methods were used under different experiment conditions. Prior to the potentiodynamic sweep, the specimen was polarized cathodically for $10 \mathrm{~min}$ at $-1.0 \mathrm{~V}_{\mathrm{SCE}}$, which might remove part of the oxide layer spontaneously formed on the specimen surface. Therefore, the corresponding $E_{\text {corr }}$ obtained from the potentiodynamic curve is more negative than the potential obtained under open circuit conditions ( $E_{O C P}$ value).

In general, the corrosion current density $\left(i_{\text {corr }}\right)$ is often used to represent the corrosion rate of a material in a corrosive solution. The relationship of the corrosion rate and temperature can be described by Arrhenius equation [41]:

$\log \left(i_{\text {corr }}\right)=\log (A)-\frac{E_{a}}{2.303 R T}$

where $E_{a}$ is the molar activation energy of the corrosion process $(\mathrm{J} /$ $\mathrm{mol}), \mathrm{R}$ is the universal gas constant $(8.314 \mathrm{~J} /(\mathrm{mol} \mathrm{K})), \mathrm{T}$ is the temperature $(\mathrm{K})$ and $\mathrm{A}$ is a constant. According to the Arrhenius equation, the activation energy values of a corrosion process can be determined from the slope of $\log \left(i_{\text {corr }}\right)$ versus $1 / T$ plots. The molar activation energy of an electrochemical reaction refers to the 

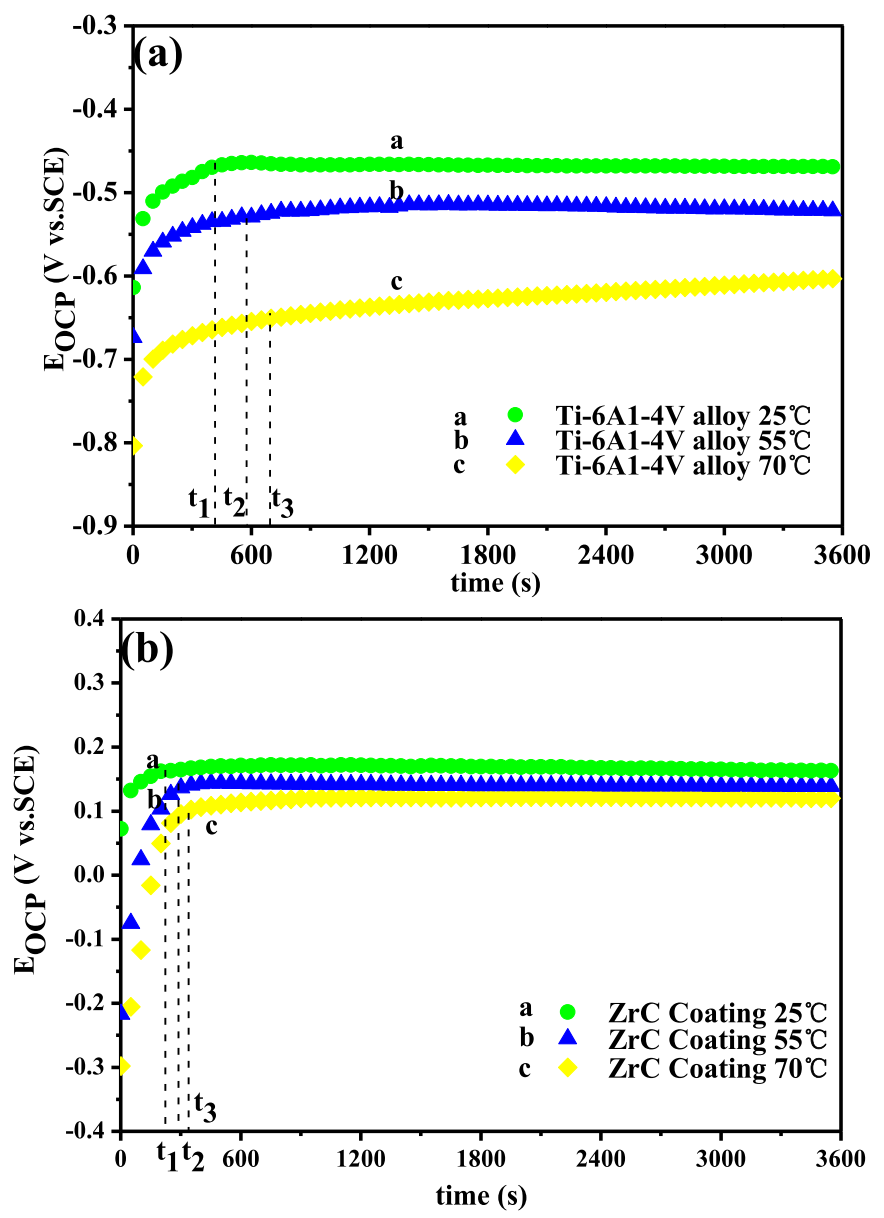

Fig. 3. The open circuit potential $\left(\mathrm{E}_{\mathrm{OCP}}\right)$ values as a function of immersion time for (a) uncoated $\mathrm{Ti}-6 \mathrm{~A} 1-4 \mathrm{~V}$ and (b) the $\mathrm{ZrC}$ coated $\mathrm{Ti}-6 \mathrm{~A} 1-4 \mathrm{~V}$ in a $0.5 \mathrm{M} \mathrm{H}_{2} \mathrm{SO}_{4}+2 \mathrm{ppm} \mathrm{HF}$ solution at three different temperatures.

energy level that must be overcome by one electron in the exchange through the electrode/electrolyte interphase. The Arrhenius equation indicates that higher $\mathrm{E}_{\mathrm{a}}$ values mean lower corrosion rates, and the higher the slope of the relation between $\log \left(i_{\text {corr }}\right)$ versus $1 / T$ is, the greater the dependence of the corrosion current density with temperature [42]. Fig. 4(c) shows Arrhenius plots of logarithm corrosion rate $\left(\log i_{\text {corr }}\right)$ versus the reciprocal of absolute temperature $(1 / \mathrm{T})$ for the $\mathrm{ZrC}$ coated and uncoated $\mathrm{Ti}-6 \mathrm{~A} 1-4 \mathrm{~V}$. It can be seen that the corrosion rate follows linear kinetics over the temperature range of measurement. The activation energies for the $\mathrm{ZrC}$ coated and bare $\mathrm{Ti}-6 \mathrm{~A} 1-4 \mathrm{~V}$ are 148 and $57 \mathrm{~kJ} / \mathrm{mol}$, respectively, indicating that the $\mathrm{ZrC}$ coated specimen exhibits a lower corrosion rate in a $0.5 \mathrm{M} \mathrm{H}_{2} \mathrm{SO}_{4}+2 \mathrm{ppm}$ HF solution than uncoated $\mathrm{Ti}-6 \mathrm{~A} 1-4 \mathrm{~V}$. The typical potential of the bipolar plate surface in contact with the anode electrode is approximately $-0.1 \mathrm{~V}_{\mathrm{SCE}}$, and that of the bipolar plate surface in contact with the cathode electrode is $+0.6 \mathrm{~V}_{\mathrm{SCE}}$ [43]. At the typical PEMFC anode working potential of $-0.1 \mathrm{~V}_{\mathrm{SCE}}$, the corrosion current densities of bare Ti-6A $1-4 \mathrm{~V}$ increase from the order of magnitude of $10^{-5}$ to $10^{-3} \mathrm{~A} \mathrm{~cm}^{-2}$ with increasing temperature. On the contrary, the corrosion potential of the $\mathrm{ZrC}$ coating is more positive than the anode operation potential of $-0.1 \mathrm{~V}_{\mathrm{SCE}}$ over the test temperature range, denoting that in the anodic environment of the fuel cell, the $\mathrm{ZrC}$ coating is in a cathodic state, and thus being completely protected from corrosion attack. At the typical PEMFC cathodic operation potential of $+0.6 \mathrm{~V}_{\mathrm{SCE}}$, the corrosion current densities for the
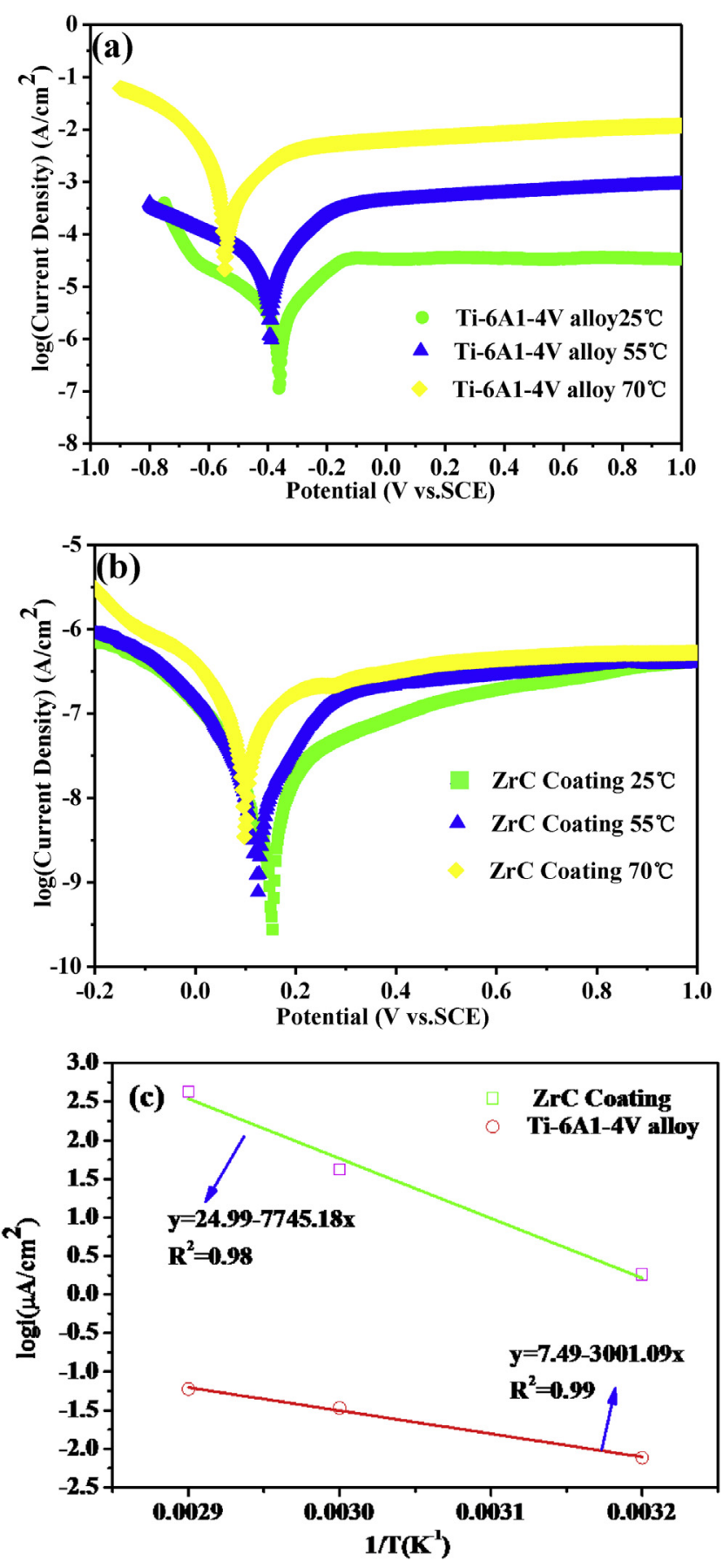

Fig. 4. Potentiodynamic polarisation curves for (a) uncoated $\mathrm{Ti}-6 \mathrm{~A} 1-4 \mathrm{~V}$ and (b) the $\mathrm{ZrC}$ coated $\mathrm{Ti}-6 \mathrm{~A} 1-4 \mathrm{~V}$ in a $0.5 \mathrm{M} \mathrm{H}_{2} \mathrm{SO}_{4}+2 \mathrm{ppm}$ HF solution obtained at three different temperatures. (c)Arrhenius plots of logarithm corrosion rate (logicorr) versus reciprocal of absolute temperature $(1 / \mathrm{T})$ for the $\mathrm{ZrC}$ coated and uncoated $\mathrm{Ti}-6 \mathrm{~A} 1-4 \mathrm{~V}$.

$\mathrm{ZrC}$ coating have decreased by $2-4$ orders of magnitude as compared to those for the bare alloy over the test temperature range, thereby drastically reducing the corrosion rate of $\mathrm{ZrC}$ coated Ti-6A1-4V. Note, such a low value meets the U.S.Department of Energy (DoE) 2015 target of $1 \mu \mathrm{A} \mathrm{cm}^{-2}$ [44].

To unlock the composition and chemical state of the passive film, XPS analysis was carried out on the $\mathrm{ZrC}$ coating after potentiostatic polarization at a potential of $+0.6 \mathrm{~V}_{\mathrm{SCE}}$ for $120 \mathrm{~min}$ in $0.5 \mathrm{M}$ $\mathrm{H}_{2} \mathrm{SO}_{4}+2 \mathrm{ppm} \mathrm{HF}$ solution open to air at $70{ }^{\circ} \mathrm{C}$. The XPS data was obtained by directly analysing the film surface, without any prior $\mathrm{Ar}$ 
Table 2

Electrochemical parameters obtained from the polarization curves for $\mathrm{ZrC}$ coated and uncoated $\mathrm{Ti}-6 \mathrm{Al}-4 \mathrm{~V}$ in $0.5 \mathrm{M} \mathrm{H}_{2} \mathrm{SO}_{4}+2 \mathrm{ppm} \mathrm{HF}$ solution under different temperature.

\begin{tabular}{llllll}
\hline Samples & $\begin{array}{l}\text { Temp } \\
\text { erature }\end{array}$ & $\begin{array}{l}\mathrm{E}_{\text {corr }} \\
\text { (V vs. SCE })\end{array}$ & $\begin{array}{l}\mathrm{i}_{\text {corr }} \\
\left(\mathrm{A} \mathrm{cm}^{-2}\right)\end{array}$ & \multicolumn{1}{l}{$\begin{array}{l}\mathrm{i}_{-0.1 \mathrm{~V}} \\
\left(\mathrm{~A} \mathrm{~cm}^{-2}\right)\end{array}$} & \multicolumn{1}{l}{$\begin{array}{l}\mathrm{i}_{\text {O.6V }} \\
\left(\mathrm{A} \mathrm{cm}^{-2}\right)\end{array}$} \\
\hline Ti-6Al-4V & $25^{\circ} \mathrm{C}$ & -0.36 & $2.24 \times 10^{-6}$ & $3.48 \times 10^{-5}$ & $3.38 \times 10^{-5}$ \\
& $55^{\circ} \mathrm{C}$ & -0.39 & $2.17 \times 10^{-5}$ & $3.65 \times 10^{-4}$ & $8.97 \times 10^{-4}$ \\
& $70^{\circ} \mathrm{C}$ & -0.55 & $7.24 \times 10^{-4}$ & $5.69 \times 10^{-3}$ & $9.77 \times 10^{-3}$ \\
ZrC coating & $25^{\circ} \mathrm{C}$ & 0.16 & $9.28 \times 10^{-9}$ & $-8.01 \times 10^{-7}$ & $2.83 \times 10^{-7}$ \\
& $55^{\circ} \mathrm{C}$ & 0.12 & $8.41 \times 10^{-8}$ & $-8.18 \times 10^{-7}$ & $4.04 \times 10^{-7}$ \\
& $70^{\circ} \mathrm{C}$ & 0.10 & $5.02 \times 10^{-7}$ & $-9.98 \times 10^{-7}$ & $5.42 \times 10^{-7}$ \\
\hline
\end{tabular}

ion etching, because the results concerning the chemical states of carbon obtained after energetic ion-bombardment were meaningless. As shown in Fig. 5(a), the wide scan spectrum of the $\mathrm{ZrC}$ coating comprises of peaks for $\mathrm{C}, \mathrm{O}$ and $\mathrm{Zr}$. Fig. 5(b)-(d) shows the high-resolution XPS spectra for $\mathrm{Zr} 3 \mathrm{~d}, \mathrm{O}$ 1s and C1s peaks collected from the passive film formed on the $\mathrm{ZrC}$ coating, respectively. The $\mathrm{Zr} 3 \mathrm{~d}$ core level spectrum (Fig.5(b)) consists of a doublet peaks from $\mathrm{Zr} 3 \mathrm{~d}_{3 / 2}$ and $\mathrm{Zr} 3 \mathrm{~d}_{5 / 2}$, with an intensity ratio $\mathrm{Zr} 3 \mathrm{~d}_{3 / 2} / \mathrm{Zr} 3 \mathrm{~d}_{5 / 2}$ of 0.6 and a spin-orbit splitting of $2.4 \mathrm{eV}$ [45]. The $\mathrm{Zr} 3 \mathrm{~d}_{5 / 2}$ peak position located at $182.3 \mathrm{eV}$, is $0.3 \mathrm{eV}$ lower than that for $\mathrm{Zr}-\mathrm{O}$ bonds in $\mathrm{ZrO}_{2}$ compounds [46], possibly originating from the formed $\mathrm{ZrO}_{2}$ containing a small amount of carbon [47]. The 01s core level spectrum (Fig. 5(c)) can be deconvoluted into two broadened peaks, with an observed shift of about1.8 eV. The peak located at $530.3 \mathrm{eV}$ with a higher intensity in the $\mathrm{O} 1 \mathrm{~s}$ spectrum is attributed to $\mathrm{O}-\mathrm{Zr}$ bonds in $\mathrm{ZrO}_{2}$ compounds, while the peak located at an energy of $532.2 \mathrm{eV}$ with a lower intensity may be attributed to carbon-to-oxygen bonding, including $\mathrm{C}-\mathrm{O}$ bonds and double $\mathrm{C}=\mathrm{O}$ bonds [48]. The C1s spectrum (Fig. 5(d)) can be deconvoluted into three components. The peaks located at 284.6, 286.3 and $288.3 \mathrm{eV}$, respectively, are ascribed to surface hydrocarbon contamination and to oxidized $\mathrm{C}-\mathrm{O}$ and $\mathrm{C}=\mathrm{O}$ states [49]. No binding energy corresponding to $\mathrm{Zr}-\mathrm{C}$ bonds, represented by a $\mathrm{C} 1 \mathrm{~s}$ binding energy at $281.1 \mathrm{eV}$, was detected, demonstrating that $\mathrm{ZrC}$ transforms into $\mathrm{ZrO}_{2}$ after potentiostatic polarization and part of carbon may be then incorporated into the $\mathrm{ZrO}_{2}$ lattice.

To gain a deeper understanding of the effect of temperature on the corrosion behaviour of the $\mathrm{ZrC}$ coating, the corroded surface morphologies of both the bare and the $\mathrm{ZrC}$ coated $\mathrm{Ti}-6 \mathrm{~A} 1-4 \mathrm{~V}$ after potentiodynamic polarization tests in $0.5 \mathrm{M} \mathrm{H}_{2} \mathrm{SO}_{4}+2 \mathrm{ppm} \mathrm{HF}$ solution at 25,45 and $70{ }^{\circ} \mathrm{C}$, were examined, as shown in Fig. 6 . From Fig. 6 (a)-(c), pits with irregular shapes appear on the wellpolished $\mathrm{Ti}-6 \mathrm{Al}-4 \mathrm{~V}$ surface, with substantial evidence of material dissolution, and the severity of the pitting attack increases with temperature. $\mathrm{H}^{+}$and $\mathrm{F}^{-}$ions present in the corrosion medium can penetrate the passive film formed on the bare $\mathrm{Ti}-6 \mathrm{Al}-4 \mathrm{~V}$ to generate pit corrosion and attack the fresh metal underneath. The underlying substrate is in active state and its potential is more negative than the outer passive film. As a result, an electrochemical corrosion with the large cathode and small anode is formed, causing a rupture of the passive film on the top. The corrosion activity of these harmful ions increases with increasing temperature, thus stimulating this electrochemical corrosion process [50]. In contrast, as shown in Fig. 6(d)-(f), the surface morphology of the $\mathrm{ZrC}$ coated $\mathrm{Ti}-6 \mathrm{~A} 1-4 \mathrm{~V}$ hardly changes with increasing temperature; the $\mathrm{ZrC}$ coating has a homogeneous and compact appearance with no evidence of pitting, suggesting that the passive films grown on the $\mathrm{ZrC}$ coating are more robust and offer better corrosion resistance in fluorine ions containing acid medium at the three test temperatures.

\subsubsection{Electrochemical impedance measurements (EIS)}

The representative Nyquist and Bode plots for the $\mathrm{ZrC}$ coated and uncoated $\mathrm{Ti}-6 \mathrm{Al}-4 \mathrm{~V}$ at their respective $\mathrm{E}_{\mathrm{OCP}}$ in $0.5 \mathrm{M}$ $\mathrm{H}_{2} \mathrm{SO}_{4}+2 \mathrm{ppm}$ HF solution under different temperatures are shown in Fig. 7(a)-(d). The response for both the $\mathrm{ZrC}$ coated and bare $\mathrm{Ti}-6 \mathrm{Al}-4 \mathrm{~V}$ in the Nyquist complex plan is essentially a specific semi-circle that differs in radius at different solution temperatures. By increasing the temperature, the diameter of capacitance
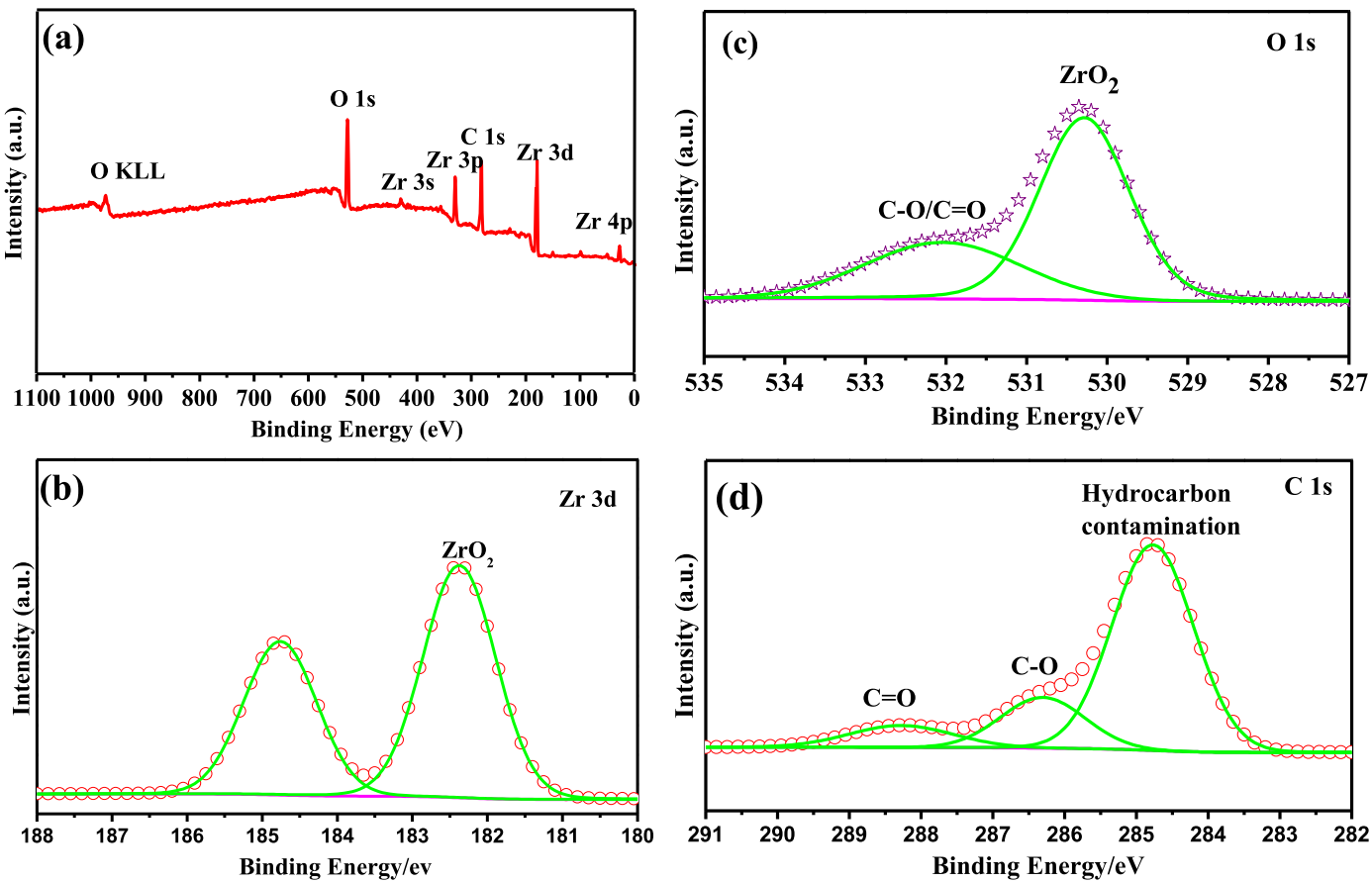

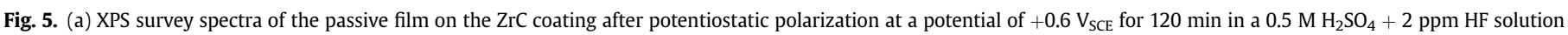
open to air at $70^{\circ} \mathrm{C}$. The high-resolution XPS spectra for $\mathrm{Zr} 3 \mathrm{~d}$ (b), $\mathrm{O} 1 \mathrm{~s}$ (c) and $\mathrm{C} 1 \mathrm{~s}$ (d) peaks collected from passive film formed on the $\mathrm{ZrC}$ coating. 

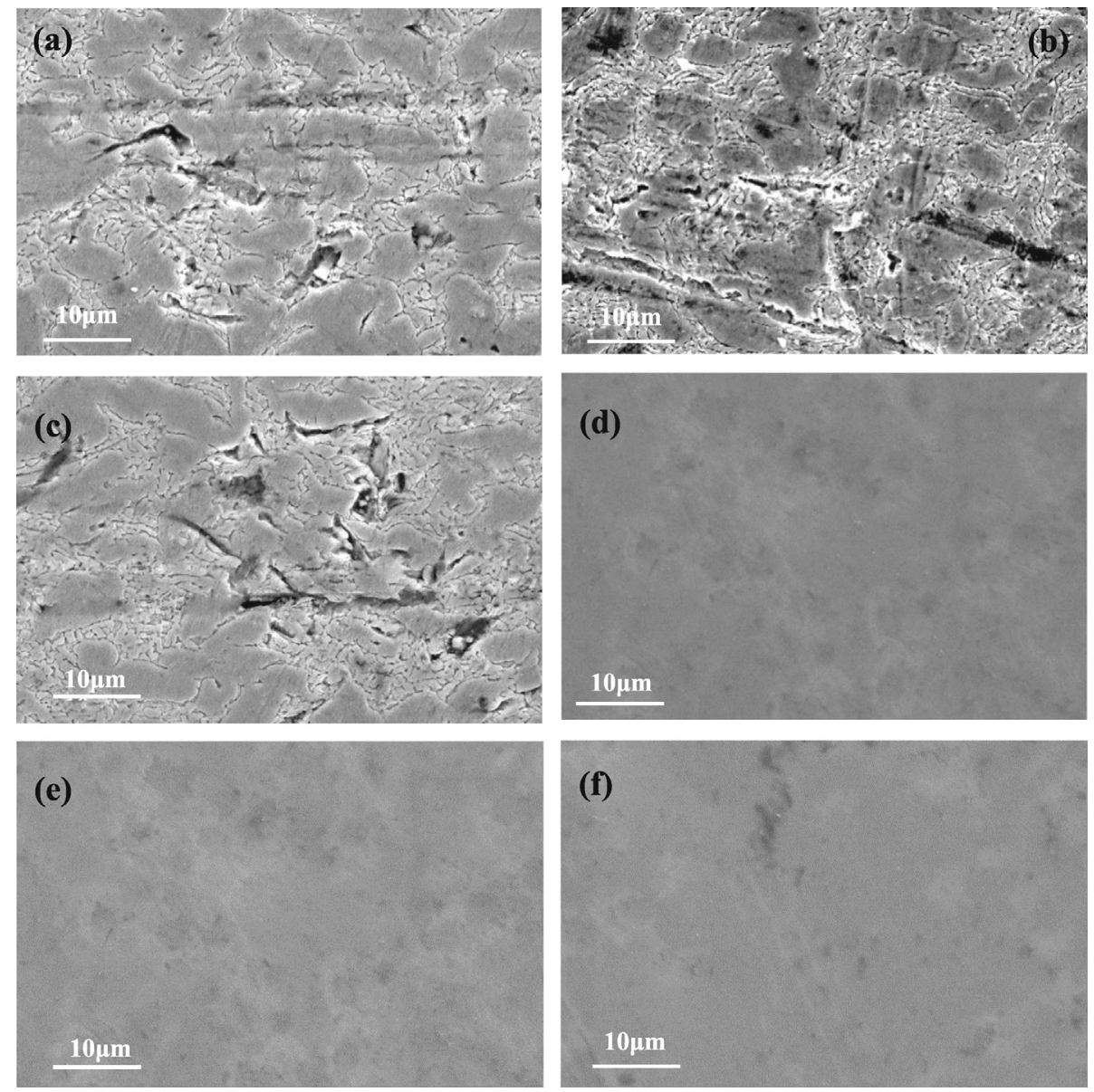

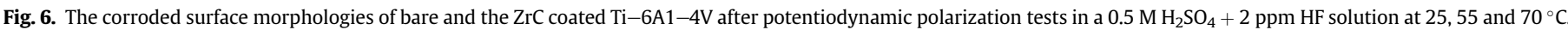
Uncoated Ti-6A1-4V: (a) $25{ }^{\circ} \mathrm{C}, 55^{\circ} \mathrm{C}$ (b) and $70{ }^{\circ} \mathrm{C}$ (c); the $\mathrm{ZrC}$ coated Ti-6A1-4V: (d) $25{ }^{\circ} \mathrm{C}, 55{ }^{\circ} \mathrm{C}$ (e) and $70{ }^{\circ} \mathrm{C}$ (f).

semicircle in the Nyquist plots and the corresponding impedance value at a frequency of $1 \mathrm{~Hz}$ in Bode-magnitude plots decrease significantly, indicative of a decrease in corrosion resistance. At any given temperature, the $\mathrm{ZrC}$ coated specimen has a significantly larger diameter of the capacitance semi-circle, wider frequency region with phase angle near $-90^{\circ}$ and greater low frequency limit $\left(|\mathrm{Z}|_{\mathrm{f} \rightarrow 0}\right)$ than bare $\mathrm{Ti}-6 \mathrm{Al}-4 \mathrm{~V}$, demonstrating a nobler electrochemical behaviour for the $\mathrm{ZrC}$ coated $\mathrm{Ti}-6 \mathrm{Al}-4 \mathrm{~V}$ in the simulated PEMFC solution. This trend is similar to observations from the potentiodynamic studies. For the bare $\mathrm{Ti}-6 \mathrm{Al}-4 \mathrm{~V}$, at the test temperatures the Nyquist plots exhibit two depressed semicircles and the Bode-phase plots have one maximum in both high and low frequency ranges, respectively. This is an indication of two distinguishable relaxation processes (time constants) taking place in the electrochemical system which are identified by EIS. Nonetheless, in the case of the $\mathrm{ZrC}$ coated specimen, the Nyquist plots show only one capacitive loop in the entire frequency range, and a broad plateau with a phase angle that is independent of the frequency maximum observed in the Bode-phase plots, and $\log |\mathrm{Z}|$ varies linearly with the $\log f$, yielding a slope close to 1 over a wide range of frequencies in the Bode-magnitude plots. Different circuit models that have been selected to fit the experimental data mainly depend upon the surface structures and nature of any passive films formed on the two specimens. In view of this, the equivalent circuits (EC) are used for modelling of the obtained EIS results, as shown in Fig. 7(e) and (f), and the extracted parameters according to the model are presented in Fig. 7(g) and (h). In Fig. 7(a)-(d), the experimental data are shown as individual points, while the theoretical spectra resulted from the fits with a relevant EC model are shown as solid lines. Very good agreement between the simulated and experimental data is obtained with the chi-square $\left(\chi^{2}\right)$ values of the order of $10^{-3}$, suggesting that the two equivalent circuit models reasonably reflect the electrochemical process responsible for the two samples.

As it can be seen, in the case of the $\mathrm{ZrC}$ coating, one time constant equivalent circuit $R_{s}\left(R_{p} Q_{p}\right)$ (i.e., modified Randles circuit, shown in Fig. $7(\mathrm{e})$ ) is proposed, which assumes that a homogeneous passive film entirely covers the $\mathrm{ZrC}$ coated $\mathrm{Ti}-6 \mathrm{Al}-4 \mathrm{~V}$. This equivalent circuit consists of an electrolyte resistance $\left(R_{S}\right)$ in series with the parallel combination of a constant phase angle element $\left(C P E, Q_{p}\right)$ and a resistance $R_{p}$. The parameter $R_{p}$, including the contributions of the passive film resistance, the charge transfer resistances and the migration of point defects mediating the growth of the passive film and dissolution of metal through it, can be used to evaluate the corrosion resistance of this alloy [51]. As shown in Fig. $7(\mathrm{~g})$, the resistance values, $R_{p}$ for the $\mathrm{ZrC}$ coated Ti-6Al-4V are rather large and are of the order of $10^{6} \sim 10^{7} \Omega \mathrm{cm}^{2}$, implying that the passive films on the $\mathrm{ZrC}$ coating can act as a protective barrier layer to resist corrosive attacks. In addition, the values for $R_{p}$ decrease as the temperature rises. The product $R \times C$ equivalent with the time constant $(\tau)$ was employed to evaluate the rate of relevant electrochemical process [52]. When one takes a reciprocal of the obtained product values, the rate of relevant electrochemical process is determined. The time constant $(\tau)$ of the 

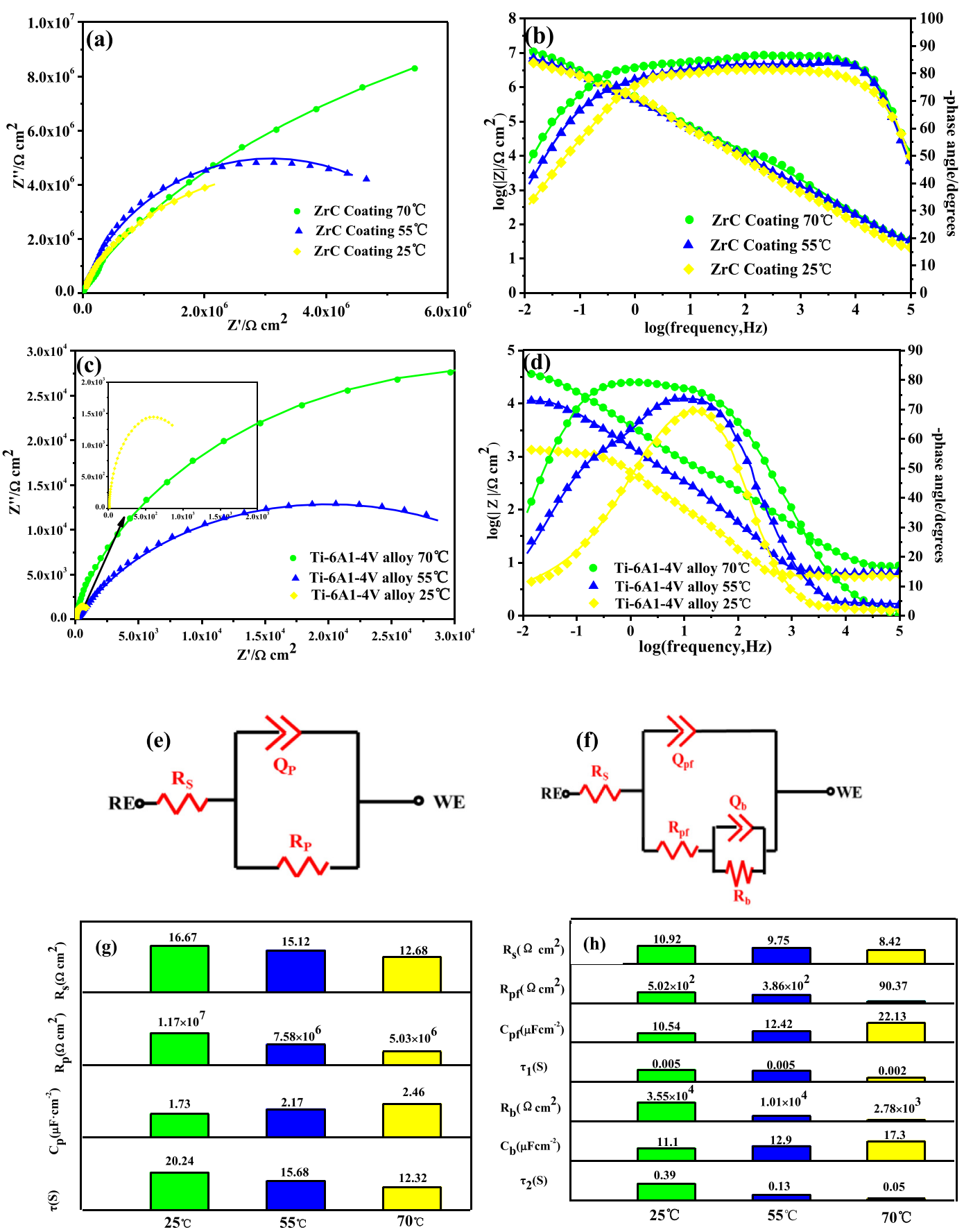

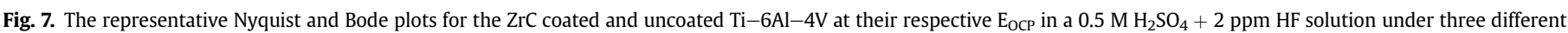

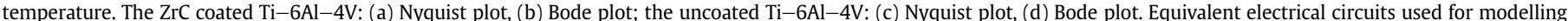

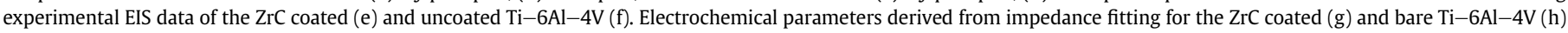
in a $0.5 \mathrm{M} \mathrm{H}_{2} \mathrm{SO}_{4}+2 \mathrm{ppm} \mathrm{HF}$ solution under three different temperatures.

$\mathrm{ZrC}$ coating reflects the total rate of the electro-chemical process including the ionic migration within the oxide film and charge transfer. It is evident that the values of $\tau$ decrease with increasing temperature, denoting an increased corrosion rate. On the contrary, the equivalent circuit $\left(R_{s}\left(Q_{p f}\left(R_{p f}\left(Q_{b} R_{b}\right)\right)\right)\right.$ presented in Fig. $7(f)$ was applied to model the impedance data of bare Ti-6Al-4V. This model assumes the formation of an oxide layer that is composed of a dense inner barrier layer and a porous outer layer [53]. In this circuit, $R$ s is the solution resistance, $R_{p f}$ and $Q_{p f}$ are the resistance and capacitance of the outer porous layer, $R_{b}$ and $Q_{b}$ are the resistance and capacitance of the inner barrier layer. As shown in Fig. 7(h), the values of $R_{b}$ and $\tau_{2}$ are $1-2$ orders of magnitude bigger than that of $R_{\text {pf }}$ and $\tau_{1}$, but much less than those of the $\mathrm{ZrC}$ coating. Because of the existence of defects on the outer porous layer, active negative ions $\left(\mathrm{F}^{-}\right)$in the solution are preferential to adsorb on these defects. As seen from Fig. 7(h), Rs becomes gradually smaller with increasing solution temperature, representing the strengthened movement of ions at a higher temperature. Meanwhile, active negative ions more easily penetrate the passive films, which lead to the increase of conductivity and poorer compactness of passive 
film. Therefore, the destructive effect of temperature on corrosion resistance is more apparent for bare Ti-6Al-4V [54].

\subsection{Interfacial contact resistance (ICR) and contact angle}

During the PEMFC operation, a gas diffusion layer is typically in contact with the bipolar plates. The ICR between the gas diffusion layer and the bipolar plate plays an important role in the PEMFC stack efficiency. It has been reported that the cost of a PEMFC stack (per $\mathrm{kW}$ ) is estimated to increase three-fold when the stack resistance increases from 0.05 to $0.2 \mathrm{~m} \Omega \mathrm{cm}^{2}$ [55]. In view of this, the best candidate materials for PEMFC bipolar plates should offer low interfacial contact resistance in addition to good corrosion resistance. The ICR as a function of compaction force for the $\mathrm{ZrC}$ coating and bare $\mathrm{Ti}-6 \mathrm{Al}-4 \mathrm{~V}$ before and after potentiostatic polarization at a cathode potential of $+0.6 \mathrm{~V}_{\mathrm{SCE}}$ for $120 \mathrm{~min}$ in $0.5 \mathrm{M}$ $\mathrm{H}_{2} \mathrm{SO}_{4}+2$ ppm HF solution open to air at $70^{\circ} \mathrm{Cis}$ shown in Fig. 8(a). The ICR values of the tested samples are found to have a similar evolution versus compaction force. That is, the ICR values decrease sharply with increasing compaction force up to $\sim 120 \mathrm{~N} \mathrm{~cm}^{-2}$ and then gradually attain a relatively stable value at higher compaction forces. The ICR values are regulated by the compaction force at low pressures, because of an increase in the effective contact area between the samples and carbon paper; however, above a certain value of compaction force, the effective contact area does not increase any further, and the surface nature and composition become the predominant factors that control ICR values [56]. A number of previous studies have also yielded similar results [57-59]. It can be seen that in both cases, a marked decrease of ICR is observed for the $\mathrm{ZrC}$ coated sample with respect to uncoated $\mathrm{Ti}-6 \mathrm{Al}-4 \mathrm{~V}$ and no perceptible difference in the ICR values is observed for the $\mathrm{ZrC}$ coated sample before and after corrosion, but in contrast a considerable increase in the ICR values occurs for bare Ti-6Al-4V after corrosion. Under the typical applied compaction force of a single cell $\left(140 \mathrm{~N} \mathrm{~cm}^{-2}\right)$, the ICR value between the bare Ti-6Al-4V and the carbon papers is $90.6 \mathrm{~m} \Omega \mathrm{cm}^{-2}$, and after 120 min potentiostatic polarization at $+0.6 \mathrm{~V}_{\mathrm{SCE}}$, the ICR value increases to $125.4 \mathrm{~m} \Omega \mathrm{cm}^{-2}$. The increase of ICR is attributed to the thickening of the passive film made of titanium oxide that inhibits the electrical conductivity [9]. At a compaction force of $140 \mathrm{~N} \mathrm{~cm}^{-2}$, the ICR value of the $\mathrm{ZrC}$ coated sample is about $9.6 \mathrm{~m} \Omega \mathrm{cm}^{-2}$, which is comparable with that of plasma-nitrided layer [60,61] and $\mathrm{Cr}$ electroplated coating [62]. After $120 \mathrm{~min}$ potentiostatic polarization at $+0.6 \mathrm{~V}_{\mathrm{SCE}}$, the ICR value of the $\mathrm{ZrC}$ coating rises to $16.7 \mathrm{~m} \Omega \mathrm{cm}^{-2}$, which is only slightly higher than the DoE's 2020 technical target of $10 \mathrm{~m} \Omega \mathrm{cm}^{-2}$, but apparently lower than that of both plasmanitrided layer [60,61] and $\mathrm{Cr}$ electroplating coating [62] after corrosion. Based on the XPS results, carbon atoms incorporated into the $\mathrm{ZrO}_{2}$ lattice may act as a dopant to $\mathrm{ZrO}_{2}$, which help improve surface conductivity and reduce the ICR value.

The presence of water in a PEMFC stack originates either from an oxygen reduction reaction at the catalyst cathode or is fed externally into the cell through humidification or the presence of cooling gases [63]. Moreover, excess water can not only block the reaction sites of neighbouring electrodes, preventing the access of reactant gases to the cell, but also accelerate the corrosion rate of the metallic bipolar plates [64]. To avoid issues associated with flooding and power degradation due to the submergence of the catalyst, the surface wettability of the bipolar plate materials should be sufficiently low enough to immediately remove any redundant water from the PEMFC stack. Contact angle measurements provide a means to estimate the wettability of a surface [65]. A high contact angle denotes a low surface wettability. Fig. 8(b) and (c) shows photographs of water droplets formed on the $\mathrm{ZrC}$ coated and bare $\mathrm{Ti}-6 \mathrm{Al}-4 \mathrm{~V}$, respectively. The average contact angle with water for the $\mathrm{ZrC}$ coating is $92.8^{\circ}$, while for bare $\mathrm{Ti}-6 \mathrm{Al}-4 \mathrm{~V}$ it is $58.8^{\circ}$. These
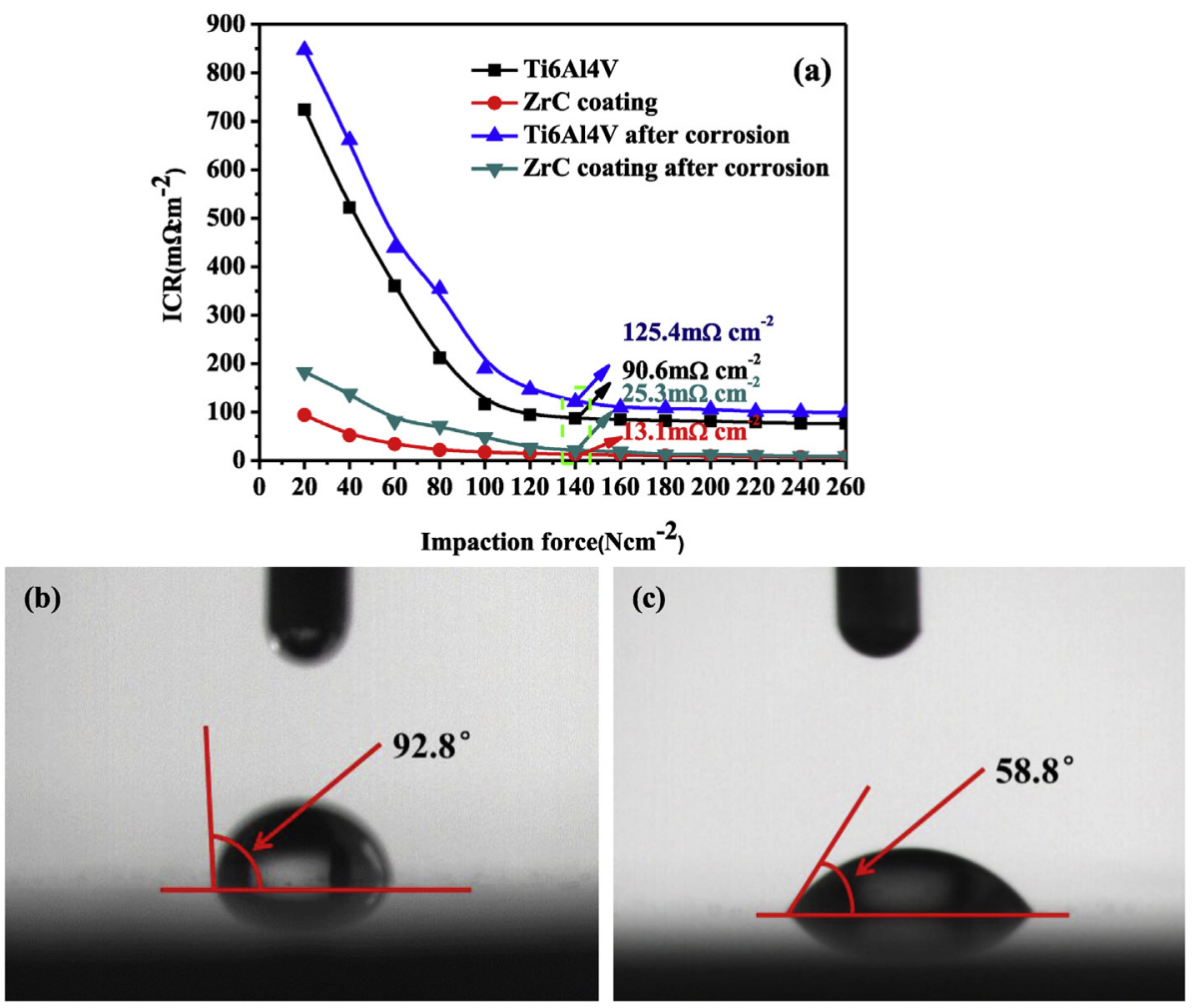

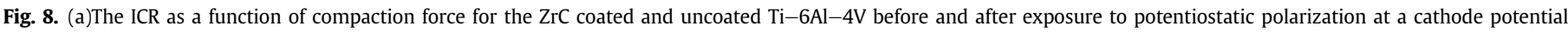
of +0.6 VSCE for $120 \mathrm{~min}$ in a $0.5 \mathrm{M} \mathrm{H}_{2} \mathrm{SO}_{4}+2 \mathrm{ppm}$ HF solution open to air at $70^{\circ} \mathrm{C}$. Photographs of a water droplet on the $\mathrm{ZrC}$ coated (b) and uncoated Ti-6Al-4V (c). 
results imply that the $\mathrm{ZrC}$-coated $\mathrm{Ti}-6 \mathrm{Al}-4 \mathrm{~V}$ alloy is much more hydrophobic than bare $\mathrm{Ti}-6 \mathrm{Al}-4 \mathrm{~V}$ alloy. The $\mathrm{ZrC}$ coating therefore provides greater protection from accumulated water flooding the electrode system [11]. Furthermore, a lower wettability also means a lower fraction of the coated area is in contact with the electrolyte solution, thus lowering the extent of any corrosion that may occur.

\section{Conclusions}

A dense and uniform nanocrystalline $\mathrm{ZrC}$ coating with a thickness of $\sim 16 \mu \mathrm{m}$ was fabricated onto a Ti-6Al-4V substrate using a double glow discharge plasma technique. The as-deposited coating showed a strong (111) texture and consisted of equiaxed grains with an average size of $\sim 12 \mathrm{~nm}$. The new coating was also adherent to the Ti-6A1-4V substrate without interfacial defects such as pinholes, micropores and microcracks. The effect of temperature on the corrosion behaviour of the $\mathrm{ZrC}$ coating in a $0.5 \mathrm{M}$ $\mathrm{H}_{2} \mathrm{SO}_{4}+2 \mathrm{ppm}$ HF solution is systematically investigated using potentiodynamic and electrochemical impedance spectroscopy (EIS) measurements. Within the temperature range studied $\left(25-70^{\circ} \mathrm{C}\right)$, the anodic current densities increase and the corrosion potentials shift toward a more negative direction with an increases in temperature. At the anode operation potential of PEMFC $(-0.1$ $\mathrm{V}_{\mathrm{SCE}}$ ), the $\mathrm{ZrC}$ coating provides cathodic protection for the substrate, while, at the cathodic operation potential of $+0.6 \mathrm{~V}_{\mathrm{SCE}}$, the corrosion current densities for the $\mathrm{ZrC}$ coating is of the order of $10^{-7} \mathrm{~A} \mathrm{~cm}^{-2}$ in test temperature range, which are lower than US DoE 2015 target of $1 \mu \mathrm{A} \mathrm{cm}{ }^{-2}$. The results of EIS measurements showed that the values of capacitance semicircle, phase angle maximum, as well as the frequency range with the phase angle near $-90^{\circ}$ are significantly larger than those of $\mathrm{Ti}-6 \mathrm{~A} 1-4 \mathrm{~V}$ in the simulated PEMFC environment. At a compaction force of $140 \mathrm{~N} \mathrm{~cm}^{-2}$, the ICR values for the $\mathrm{ZrC}$ coating were much lower than that of bare $\mathrm{Ti}-6 \mathrm{~A} 1-4 \mathrm{~V}$ before and after corrosion, and were comparable with the DoE's 2020 technical target of $10 \mathrm{~m} \Omega \mathrm{cm}^{-2}$. Moreover, the $\mathrm{ZrC}$ coating is more hydrophobic than uncoated $\mathrm{Ti}-6 \mathrm{~A} 1-4 \mathrm{~V}$, which prevents accumulated water from flooding the electrode system and at the same time mitigated the extent of corrosive attack. The unique combination of high corrosion resistance, good electrical conductivity and low surface wettability therefore renders the $\mathrm{ZrC}$ nanocrystalline coating an attractive choice for enhancing the surface performance and durability of bipolar plates in PEMFCs.

\section{Acknowledgements}

The authors acknowledge the financial support of the National Natural Science Foundation of China under Grant No. 51374130, the Aeronautics Science Foundation of China under Grant No. 2013ZE52058 and the Australian Research Council Discovery Project under Grant No. DP150102417.

\section{References}

[1] V.V. Nikam, R.G. Reddy, S.R. Collins, P.C. Williams, G.H. Schiroky, G.W. Henrich, Electrochim. Acta 53 (2008) 2743-2750.

[2] P. Ekdunge, M. Råberg, Int. J. Hydrog. Energy 23 (1998) 381-385.

[3] R. Taherian, J. Power Sources 265 (2014) 370-390.

[4] V.V. Nikam, R.G. Reddy, J. Power Sources 152 (2005) 146-155.

[5] V.V. Nikam, R.G. Reddy, Electrochim. Acta 51 (2006) 6338-6345.

[6] P.L. Hentall, J.B. Lakeman, G.O. Mepsted, P.L. Adcock, J.M. Moore, J. Power Sources 80 (1999) 235-241.

[7] N. Heras, E.P.L. Roberts, R. Langton, D.R. Hodgson, Energy Environ. Sci. 2 (2009) 206-214.
[8] P. Hamilton, B. Pollet, Fuel Cells 10 (2010) 489-509.

[9] J.H. Young, H.S. Yang, G. Prabhu, P.N. Branko, J. Power Sources 194 (2009) 972-975.

[10] C.Y. Chung, S.K. Chen, P.J. Chiu, M.H. Chang, T.T. Hung, T.H. Ko, J. Power Sources 176 (2008) 276-281.

[11] H. Tawfik, Y. Hung, D. Mahajan, J. Power Sources 163 (2007) 755-767.

[12] S.H. Wang, J. Peng, W.B. Lui, J. Power Sources 160 (2006) 485-489.

[13] S.H. Wang, J. Peng, W.B. Lui, J.S. Zhang, J. Power Sources 162 (2006) 486-491.

[14] J. Pettersson, B. Ramsey, D. Harrison, J. Power Sources 157 (2006) 28-34.

[15] J.H. Young, H.S. Yang, G. Prabhu, N.P. Branko, J. Power Sources 195 (2010) 1950-1956.

[16] D. Sciti, S. Guicciardi, M. Nygren, Scr. Mater. 59 (2008) 638-641.

[17] C.S. Chen, C.P. Liu, J. Non-Cryst. Solids 351 (2005) 3725-3729.

[18] R. Fileding, M. Meyer, J.F. Jue, J. Gan, J. Nucl. Mater. 371 (2007) 243-249.

[19] B. Navinxek, P. Panjan, A. Cvelbar, Surf. Coat. Technol. 155 (1995) 74-75.

[20] J. Barranco, F. Barreras, A. Lozano, M. Maza, J. Power Sources 196 (2011) 4283-4289.

[21] J. Xu, D. Lai, Z. Xie, P. Munroe, Z.T. Jiang, J. Mater. Chem. 22 (2012) 2596-2606.

[22] L. Wang, Juncai Sun, P. Li, J. Sun, Y. Lv, B. Jing, S. Li, Shijun Ji, Z. Wen, Int. J. Hydrog. Energy 37 (2012) 5876-5883.

[23] T. Fukutsuka, T. Yamaguchi, S.I. Miyano, Y. Matsuo, Y. Sugie, Z. Ogumi, J. Power Sources 174 (2007) 199-205.

[24] M.I. Jones, I.R. McColl, D.M. Gran, Surf. Coat. Technol. 132 (2000) 143-151.

[25] C.Y. Su, C.T. Lu, W.T. Hsiao, W.H. Liu, Thin Solid Films 544 (2013) 170-174.

[26] U.C. Oh, J.H. Je, J. Appl. Phys. 74 (3) (1993) 1692-1696.

[27] H.S. Kim, D.J. Choi, J. Am. Ceram. Soc. 82 (1999) 331-337.

[28] M. Ding, H. Zhang, C. Zhang, X. Jin, Surf. Coat. Technol. 224 (2013) 34-41.

[29] A.L. Patterson, Phys. Rev. 56 (1939) 978-982.

[30] L.P. Wang, K.Y. Fu, X.B. Tian, B.Y. Tang, P.K. Chu, Mater. Sci. Eng. A 336 (2002) 75-80.

[31] L.V. Santos, V.J.T. Airoldi, E.J. Corat, J. Nogueira, N.F. Leite, Surf. Coat. Technol. 200 (2006) 2587-2593.

[32] Y. Zhou, M. Li, Y. Cheng, Y.F. Zheng, T.F. Xi, S.C. Wei, Surf. Coat. Technol. 228 (2013) S2-S6.

[33] O. Durst, J. Ellermeier, C. Berger, Surf. Coat. Technol. 203 (2008) 848-854.

[34] D.H. Hur, Y.S. Park, Corrosion 62 (2006) 745-750.

[35] H.G. Jiang, M. Rühle, E.J. Lavernia, J. Mater. Res. 14 (1999) 549-559.

[36] J. Fornell, N. Van Steenberge, A. Varea, E. Rossinyol, E. Pellicer, S. Suriñach, M.D. Baró, J. Sort, J. Mech. Behav. Biomed. 4 (2011) 1709-1717.

[37] L.F. Garfias-Mesias, J.M. Sykes, Corros. Sci. 41 (1999) 959-987.

[38] R.S. Tovar, M.T. Montañés, J.G. Antón, Corros. Sci. 52 (2010) 722-733.

[39] S.J. Ahn, H.S. Kwon, Electrochim. Acta 49 (2004) 3347-3353.

[40] R.M. Carranza, M.G. Alvarez, Corros. Sci. 38 (1996) 909-925.

[41] R.M. El-Sherif, K.M. Ismail, W.A. Badawy, Electrochim. Acta 49 (2004) 5139-5150.

[42] P.W. Atkins, Physical Chemistry, sixth ed., Oxford University Press, USA, 1998.

[43] H. Wang, M.A. Sweikart, J.A. Turner, J. Power Sources 115 (2003) 243-251.

[44] R.A. Antunes, M.C.L. Oliveira, G. Ett, V. Ett, Int. J. Energy Res. 35 (2010) 3632-3647.

[45] M. Matsuoka, S. Isotani, W. Sucasaire, N. Kuratani, K. Ogata, Surf. Coat. Technol. 202 (2008) 3129-3155.

[46] C. Monticelli, F. Zucchi, A. Pagnoni, M.D. Colle, Electrochim. Acta 50 (2005) 3461-3469.

[47] V. Craciun, E.J. McCumiskey, M. Hanna, C.R. Taylor, J. Eur. Ceram. Soc. 33 (2013) 2223-2226.

[48] J.L. Figueiredo, M.F.R. Pereira, M.M.A. Freitas, J.J.M. Órfão, Carbon 37 (1999) 1379-1389.

[49] G. Beamson, D. Briggs, High Resolution XPS of Organic Polymers: the Scienta ESCA300 Database, J. Wiley \& Sons, Chichester, 1992.

[50] Y. Yang, L. Guo, H. Liu, J. Power Sources 195 (2010) 5651-5659.

[51] H. Krawiec, V. Vignal, E. Schwarzenboeck, J. Banas, Electrochim. Acta 104 (2013) 400.

[52] A. Arutunow, K. Darowicki, Corros. Sci. 53 (2008) 4387-4395.

[53] M.G. Hosseini, M. Jafari, R. Najjar, Surf. Coat. Technol. 206 (2011) 280-286.

[54] X. Xu, Z. Bai, Y. Feng, Q. Ma, W. Zhao, Appl. Surf. Sci. 280 (2013) 641-645.

[55] A. Kraytsberg, M. Auinat, Y. Ein-Eli, J. Power Sources 164 (2007) 697-703.

[56] R. Tian, J. Sun, J. Mater. Res. 35 (2011) 772-780.

[57] D.P. Davies, P.L. Adcock, M. Turpin, S.J. Rowen, J. Appl. Elctrochem. 30 (2000) $101-105$.

[58] D.P. Davies, P.L. Adcock, M. Turpin, S.J. Rowen, J. Power Sources 86 (2000) $237-242$.

[59] H. Wang, G. Teeter, J.A. Turner, J. Electrochem. Soc. 152 (2005) B99-B104.

[60] R. Tian, J. Sun, L. Wang, Int. J. Hydrog. Energy 31 (2006) 1874-1878.

[61] R. Tian, J. Sun, J. Wang, Int. J. Hydrog. Energy 33 (2008) 7507-7512.

[62] J. Wang, J. Sun, S. Li, Z. Wen, S. Ji, Int. J. Hydrog. Energy 37 (2012) 1140-1144.

[63] T. Ous, C. Arcoumanis, J. Power Sources 240 (2013) 558-582.

[64] L. Wang, J. Sun, P. Li, B. Jing, S. Li, Z. Wen, S. Ji, J. Power Sources 208 (2012) 397-403.

[65] Y.G. Takei, T. Aoki, K. Sanui, N. Ogata, Y. Sakurai, T. Okano, Macromolecules 27 (1994) 6163-6166. 